\title{
HEV, TTV and GBV-C/HGV markers in patients with acute viral hepatitis
}

A.C. Lyra ${ }^{1,3}$, J.R.R. Pinho ${ }^{2}$, L.K. Silva ${ }^{4}$, L. Sousa ${ }^{2}$, C.P. Saraceni' ${ }^{2}$, E.L. Braga ${ }^{3}$, J.E. Pereira ${ }^{3}$, M.A.S. Zarife ${ }^{5}$, M.G. Reis ${ }^{4}$, L.G.C. Lyra ${ }^{3}$, L.C. da Silva ${ }^{1}$ and F.J. Carrilho ${ }^{1}$

\author{
${ }^{1}$ Departamento de Gastroenterologia, Universidade de São Paulo, São Paulo, \\ SP, Brasil \\ ${ }^{2}$ Instituto Adolfo Lutz, São Paulo, SP, Brasil \\ ${ }^{3}$ Serviço de Gastro-Hepatologia, Universidade Federal da Bahia and Hospital São \\ Rafael, Salvador, BA, Brasil \\ ${ }^{4}$ Fundação Oswaldo Cruz (FioCruz), Salvador, BA, Brasil \\ ${ }^{5}$ Laboratório Central da Bahia (LACEN), Salvador, BA, Brasil
}

\section{Correspondence \\ A.C. Lyra \\ R. Sócrates Guanaes Gomes, 84/401 \\ 40283-320 Salvador, BA \\ Brasil \\ Fax: +55-71-452-9589 \\ E-mail: aclyra@atarde.com.br}

Research supported in part by Alves de Queiroz Family Fund for Research.

Publication supported by FAPESP.

Received February 19, 2004

Accepted January 3, 2005

\begin{abstract}
The aim of the present study was to evaluate the prevalence of HEV, TTV and GBV-C/GBV-C/HGV in patients with acute viral hepatitis $\mathrm{A}, \mathrm{B}$ and non-A-C. We evaluated sera of 94 patients from a sentinel program who had acute hepatitis $A(N=40), B(N=42)$ and non- $A$ $\mathrm{C}(\mathrm{N}=12) ; 71$ blood donors served as controls. IgM and anti-HEV IgG antibodies were detected by enzyme immunoassay using commercial kits. TTV and GBV-C/HGV were detected by nested PCR; genotyping was done by sequencing and phylogenetic analysis. Anti-HEV IgG was present in 38,10 and $17 \%$ of patients with hepatitis A, B and nonA-C. Four patients with hepatitis A and 1 with non-A-C hepatitis also had anti-HEV IgM detected in serum. TTV was detected in $21 \%$ of patients with acute hepatitis and in $31 \%$ of donors. GBV-C/HGV was detected in $9 \%$ of patients with hepatitis, and in $10 \%$ of donors. We found TTV isolates of genotypes 1, 2, 3, and 4 and GBV-C/HGV isolates of genotypes 1 and 2. Mean aminotransferase levels were lower in patients who were TTV or GBV-C/HGV positive. In conclusion, the detection of anti-HEV IgM in some acute hepatitis A cases suggests co-infection with HEV and hepatitis E could be the etiology of a few cases of sporadic non-A-C hepatitis in Salvador, Brazil. TTV genotype 1,2, 3 and 4 isolates and GBV-C/HGV genotype 1 and 2 strains are frequent in the studied population. TTV and GBV-C/HGV infection does not appear to have a role in the etiology of acute hepatitis.
\end{abstract}

Key words

- Acute hepatitis

- Hepatitis E

- TTV

- GBV-C/HGV

- Genotype

- Brazil

\section{Introduction}

Acute viral hepatitis A, B, and non-A-C remains an important cause of morbidity in cities of Northeastern Brazil. The prevalence of hepatitis A virus (HAV) infection closely correlates with the degree of environmental sanitation and the prevailing socioeconomic and hygiene conditions. In Brazil, seroprevalence studies have indicated a high prevalence of anti-HAV antibodies in the adult population (1-3).

Anti-HBc is one of the main serological markers used to detect hepatitis B virus (HBV) 
infection and its seroprevalence has been reported to be approximately $8 \%$ in several regions of Brazil, including the Northeast $(4,5)$. Following acute hepatitis B, chronic infection occurs in $1.7 \%$ of cases in some areas of Brazil (6). Sexual transmission appeared to play a major role in the spread of HBV in a Brazilian study (7).

A few cases of acute non-A-C hepatitis have been reported in the city of Salvador, Bahia, Brazil, and these patients were less likely to evolve toward chronic infection compared with acute hepatitis C (8).

Hepatitis E virus (HEV) is a singlestranded positive sense RNA virus whose genome was first cloned and sequenced in 1990 and is approximately $7.5 \mathrm{~kb}$ in length $(9,10)$. It has been recognized as an etiologic agent responsible for epidemic and endemic cases of acute viral hepatitis worldwide, especially in developing countries (11-13). Previous studies have demonstrated seropositivity for anti-HEV IgG antibodies in populations from Brazil, including patients with non-A-C hepatitis, suggesting that HEV may be responsible for some cases of acute non-A-C hepatitis in this country (14-16). Nevertheless, detection of anti-HEV IgM in serum of patients with acute hepatitis has not been reported in Brazil.

In 1997, a new virus designated transfusion-transmitted virus (TTV) was isolated from the serum of a patient with post-transfusion non-A-E hepatitis who was GBV-C/ HGV-RNA negative (17). TTV is a singlestranded, circular, non-enveloped DNA virus with at least 3800 base pairs and at least two open reading frames (18). The results of studies concerning the role of TTV in acute and chronic liver diseases have been controversial (19-21).

GBV-C/GBV-C/HGV was initially reported as a putative non-A-C hepatitis virus; however, there is increasing evidence that this virus does not cause hepatitis $(22,23)$. Recently, GBV-C viremia has been associated with prolonged survival among HIV- positive subjects $(24,25)$.

The aim of the present study was to evaluate the prevalence of HEV, TTV and GBV$\mathrm{C} / \mathrm{GBV}-\mathrm{C} / \mathrm{HGV}$ infection in patients with acute viral hepatitis A, B and non-A-C from a sentinel program in the city of Salvador, Northeastern Brazil, and to determine if coinfections with these viruses correlated with the severity of the necro-inflammatory activity.

\section{Material and Methods}

\section{Selection of patients and donors}

We evaluated sera from 94 patients who attended the acute hepatitis outpatient service of the Federal University of Bahia between 1995 and 1999. These patients were referred by primary care public institutions in the city of Salvador, Bahia, through a sentinel program for hepatitis. All public primary care health units in the city of Salvador were instructed to refer patients with jaundice to the central laboratory of the State of Bahia located in the city of Salvador. These primary care units assist subjects who live in neighborhoods of low socioeconomic level. Patients were subjected to laboratory tests, serum samples were stored and patients with alanine aminotransferase (ALT) levels higher than twice the upper limit of normal were referred to the outpatient service of the Federal University of Bahia and evaluated by a nurse and a hepatologist. If clinical suspicion of acute hepatitis was confirmed the patient was subjected to a complete laboratory work-up that included viral markers.

Between 1995 and 1999, approximately 310 patients attended the service through the sentinel program. Of these, 94 were selected because all had acute hepatitis A, B or nonA-C, and had serum samples stored at $-70^{\circ} \mathrm{C}$. In addition, we included non-A-C hepatitis patients who had been diagnosed after being subjected to all laboratory tests required to 
exclude other liver diseases.

Sera from 71 volunteer blood donors were used as controls. These subjects had donated blood at the main Blood Center in the State of Bahia (HEMOBA), located in the city of Salvador. We selected 71 consecutive subjects who had donated blood in 1999 and who fulfilled criteria for blood donation. Thus, all were seronegative for all serologic tests performed at the Blood Center, including tests for hepatitis B surface antigen (HBsAg) and antibody to hepatitis B core antigen (anti-HBc) and hepatitis $\mathrm{C}$ antibody (anti-HCV), and all had normal ALT levels.

The institutional review boards approved the study and the protocol conformed to the ethical guidelines of the Helsinki declaration and resolution 196/CONEP/MS.

\section{Case definition}

All patients had signs and symptoms of acute hepatitis, as well as ALT and aspartate aminotransferases (AST) at least two times the upper limit of normal. Patients were further divided into three categories according to the following serological features:

Acute hepatitis A. This group consisted of 40 patients seropositive for anti-HAV IgM and seronegative for anti-HBc IgM, HBsAg and anti-HCV by enzyme immunoassay (EIA).

Acute hepatitis $B$. This group contained 42 patients positive for $\mathrm{HBsAg}$ and anti$\mathrm{HBc} \operatorname{IgM}$ and negative for anti-HAV and anti-HCV by EIA.

Acute non-A-C hepatitis. This group included 12 patients negative for anti-HAV, anti-HBc IgM, HBsAg and anti-HCV. All patients were also HCV-RNA negative by PCR (26). All patients had hepatic autoantibody titers lower than $1 / 40$; had no history of potentially hepatotoxic drug use in the 15 days that preceded the beginning of symptoms; all had an estimated alcohol consumption of less than $40 \mathrm{~g} / \mathrm{day}$, and an abdominal ultrasonography showing normal liver texture and no dilated common bile duct. Serum ceruloplasmin was measured in patients who were less than 30 years old and all were found to have normal levels.

\section{Laboratory methods}

Serological tests. Anti-HAV IgM and anti-HBc and $\mathrm{HBsAg}$ IgM were detected by EIA (Abbott Laboratories, Abbott Park, IL, USA, and Wiesbaden-Delkenheim, Germany). Anti-HCV was tested using a second-generation EIA (Abbott Laboratories). Anti-HEV IgM and anti-HEV IgG were assayed by EIA (Genelabs Diagnostics, Singapore, and Abbott Laboratories, respectively). All assays were performed in duplicate according to manufacturer instructions.

$T T V$-DNA detection. TTV-DNA was detected in serum by a nested PCR assay using sense primers NG059 and NG061, and antisense primer NG063 described previously (27); the second anti-sense oligonucleotide (5' GTK GGK TAC CAY TTA GCT CTC ATT C 3') was denoted JR01. Briefly, nucleic acid was extracted as previously reported (28) and amplified using standard PCR conditions by a first round of PCR performed with primers NG059 and JR01 for 35 cycles $\left(94^{\circ} \mathrm{C}, 30 \mathrm{~s} ; 60^{\circ} \mathrm{C}, 45 \mathrm{~s} ; 72^{\circ} \mathrm{C}, 60 \mathrm{~s}\right)$, plus an additional cycle of $72^{\circ} \mathrm{C}$ for $7 \mathrm{~min}$. Identical conditions and primers NG061 and NG063 were used for the second round of amplification. After $1.5 \%$ agarose gel electrophoresis, samples producing a single band of $271 \mathrm{bp}$ were considered to be positive. Stringent precautions were taken to avoid contamination as previously described (29).

$G B V-C / H G V-R N A$ detection. GBV-C/ HGV-RNA was detected in serum by RTnested PCR assay of two regions, NS3 and 5'NCR, as previously described (30). Reverse transcription was carried out using Moloney murine leukemia virus reverse transcriptase (Invitrogen, San Diego, CA, USA) and random hexamers (Invitrogen). For the nested PCR, standard PCR conditions and 
sets of primers for the NS3 region (NS3.2a.2, NS3.2-s1, GBVc-a1, GBVc-s1) $(22,31)$ and 5'NCR region (5'NCR-s1, 5'NCR-a1, 5'NCR-s2, 5'NCR-a2) (32) were used. A PCR "touchdown" thermocycling protocol was used for the NS3 region $(22,30)$. After agarose gel electrophoresis, samples producing a single band of $171 \mathrm{bp}$ for the NS3 region, and of $203 \mathrm{bp}$ for the 5'NCR region were considered to be positive.

Sequencing and genotyping. Both strands of TTV and GBV-C/HGV PCR products were sequenced using the ABI Prism BigDye Terminator Ready Reaction Kit version 1.0 (Applied Biosystems, Foster City, CA, USA). Reactions were analyzed with an automated DNA sequencer (ABI model 377). Sequences were validated after visual inspection and analysis using the Phred-Phrap-Consed software, and then aligned using the CLUSTAL $\mathrm{X}$ software, version 1.81 (33). TTV and GBV-C/HGV isolates were genotyped by comparison of nucleotide or amino acid mutations with sequences of previously published genomes, and by phylogenetic analy-

Table 1. Clinical features of the 94 patients studied.

\begin{tabular}{|c|c|c|c|c|c|}
\hline Group & $\begin{array}{l}\text { Number } \\
\text { of patients }\end{array}$ & $\begin{array}{l}\text { Sex (male: } \\
\text { female) }\end{array}$ & $\begin{array}{c}\text { Age (years) } \\
(\text { mean } \pm \text { SD)* }\end{array}$ & $\begin{array}{l}\mathrm{ALT}(x \cup L N)^{a} \\
(\text { mean } \pm \mathrm{SD})^{* *}\end{array}$ & $\begin{array}{l}\text { AST }(x \cup L N)^{a} \\
(m e a n \pm S D)^{* * *}\end{array}$ \\
\hline Hepatitis A & 40 & $30: 10$ & $14.28 \pm 8.95$ & $18.55 \pm 14.48$ & $312.05 \pm 11.64$ \\
\hline Hepatitis B & 42 & $25: 17$ & $32.19 \pm 12.99$ & $30.93 \pm 20.77$ & $26.36 \pm 21.62$ \\
\hline $\begin{array}{l}\text { Hepatitis } \\
\text { non-A-C }\end{array}$ & 12 & $4: 8$ & $31.70 \pm 6.30$ & $19.00 \pm 12.83$ & $8.83 \pm 7.06$ \\
\hline Total & 94 & 59:35 & $24.50 \pm 15.58$ & $24.14 \pm 18.31$ & $18.03 \pm 18.07$ \\
\hline
\end{tabular}

aAlanine aminotransferase (ALT) and aspartate aminotransferase (AST) levels are reported as multiple upper limit of normal ( $x$ ULN). The normal range for ALT is $12-50$ $\mathrm{U} / \mathrm{l}$ and the normal range for AST is $12-46 \mathrm{U} / \mathrm{l}$.

${ }^{*}$ Comparison of age: $P<0.001$ for comparison of age between the three groups (Kruskal-Wallis test); $P<0.05$ for comparison of hepatitis $A$ vs hepatitis $B$ group and for comparison of hepatitis A vs non-A-C (Dunn test); $P=N S$ for comparison of hepatitis B vs non-A-C (Dunn test).

${ }^{*}$ Comparison of ALT levels: $\mathrm{P}=0.007$ for comparison of ALT levels between the three groups (Kruskal-Wallis test); $\mathrm{P}<0.05$ for comparison of hepatitis $\mathrm{A} v \boldsymbol{v}$ hepatitis $\mathrm{B}$ group; $P=N S$ for comparison of hepatitis $A$ vs non-A-C and for comparison of hepatitis B vs non-A-C (Dunn test).

*** Comparison of AST levels: $\mathrm{P}<0.001$ for comparison of AST levels between the three groups (Kruskal-Wallis test); $\mathrm{P}<0.05$ for comparison of hepatitis $\mathrm{A}$ vs hepatitis $\mathrm{B}$ group; $P<0.05$ for comparison of hepatitis $B$ vs non-A-C (Dunn test); $P=N S$ for comparison of hepatitis A vs non-A-C (Dunn test). sis using the neighbor-joining method of the MEGA program (version 2.1) (34); the distance matrix was calculated with the Kimura 2-parameter model (35).

\section{Statistical analysis}

Data regarding continuous variables are reported as means $\pm \mathrm{SD}$. The means for the three groups with acute hepatitis were compared by Kruskal-Wallis ANOVA followed by Dunn's test. The means for TTV (or GBV-C/HGV)-positive and TTV (or GBV$\mathrm{C} / \mathrm{HGV}$ )-negative patients were compared by the Mann-Whitney U-test. Proportions were compared by the chi-square test or Fisher exact test when appropriate. All analyses were performed using the SPSS package (SPSS for Windows release 11.0; SPSS Inc., Chicago, IL, USA) and the SigmaStat for Windows software (version 2.03, SPSS Inc.). A $P$ value $\leq 0.05$ was considered to be statistically significant.

\section{Results}

The clinical features of the patients are summarized in Table 1. Fifty-nine patients were males and 35 were females. Mean age was higher for patients with hepatitis B and non-A-C compared to patients with hepatitis A. Mean ALT and AST levels were highest in the group of patients with acute hepatitis B.

Anti-HEV IgG was detected more frequently in patients with acute hepatitis A $(38 \%)$ than in patients with acute hepatitis B $(10 \%)(\mathrm{P}=0.003$; Figure 1). Anti-HEV IgG was detected in 15 patients with acute hepatitis A and 4 patients with acute hepatitis B; 2 patients from the non-A-C group were also anti-HEV IgG positive. Four of the 15 patients with acute hepatitis $\mathrm{A}$ and 1 of the 2 patients with non-A-C hepatitis who had anti-HEV IgG were also positive for antiHEV IgM, while none of the 4 patients from the hepatitis B group was positive (Figure 1). 
Among the 4 patients with serological markers for HAV and HEV, mean ALT and AST levels were $9.3 \pm 4.6$ and $7.5 \pm 4.4$ times the upper limit of normal, respectively, while among the remaining 36 patients infected only with HAV, ALT and AST levels were $19.6 \pm 14.9$ and $12.6 \pm 12.1$ times the upper limit of normal $(\mathrm{P}=0.179$ and $\mathrm{P}=0.417$ for comparison of ALT and AST, respectively).

Serum TTV-DNA was detected in 20 of 94 patients $(21 \%)$ with acute hepatitis, and in 22 of 71 blood donors (31\%). TTV was detected in 8 of $40(20 \%)$ patients with acute hepatitis A, 11 of $42(26 \%)$ with acute hepatitis B, and 1 of 12 (8\%) patients with non-A$\mathrm{C}$ hepatitis (Table 2). There was no statistically significant difference in mean age or mean aminotransferase levels between TTVpositive and TTV-negative patients (Table $3)$.

TTV genotyping was carried out for 26 of 42 subjects who were TTV positive (GenBank accession numbers AY137347AY137372). Six of these subjects had acute hepatitis B, 2 had acute hepatitis A and 18 were blood donors. They were selected according to the availability of extra amounts of serum. We found TTV isolates of genotypes 1a, 1b, 2, 3, and 4 (Figure 2). The distribution of TTV genotypes showed that genotype 1 was the most prevalent in the study population.

Serum GBV-C/HGV-RNA was detected in 13 of 165 individuals using primers for the NS3 region (8\%), and in 15 of 165 using primers of the 5'NCR region (9\%). GBV-C/ HGV-RNA was detected in 6 (NS3 region) and 8 (5'NCR region) of 94 patients (6 and $9 \%$, respectively) with acute hepatitis, and in 7 of 71 (10\%) blood donors, for both the NS3 and 5'NCR regions (Table 2). Mean ALT levels were lower in GBV-C/HGVRNA-positive patients compared to GBVC/HGV-RNA-negative patients, although this difference did not reach statistical significance.

GBV-C/HGV genotyping was carried out

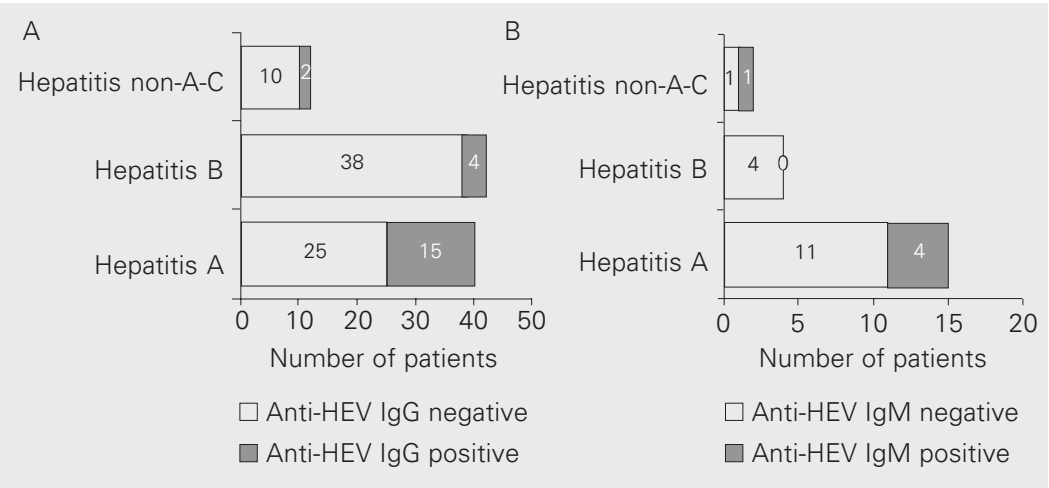

Figure 1. A, Prevalence of serum anti-HEV IgG antibodies in patients with acute hepatitis. Anti-HEV IgG was significantly more prevalent in patients with hepatitis A compared to the hepatitis $B$ group $(P=0.003$, chi-square test). Comparison between hepatitis $A$ vs non-A-C groups showed $P=0.294$, and comparison between the hepatitis $B$ group and the non-A-C hepatitis group showed $\mathrm{P}=0.605$ (Fisher exact test). $B$, Prevalence of serum anti-HEV IgM antibodies in patients with acute hepatitis who were anti-HEV IgG positive.

Table 2. Prevalence of serum TTV-DNA and GBV-C/HGV-RNA in patients with acute hepatitis and in blood donors.

\begin{tabular}{lcccc}
\hline Group & $\begin{array}{c}\text { Number of } \\
\text { patients }\end{array}$ & $\begin{array}{c}\text { TTV-DNA- } \\
\text { positive } \\
\text { patients (\%) }\end{array}$ & $\begin{array}{c}\text { GBV-C/HGV- } \\
\text { NS3-positive } \\
\text { patients (\%) }\end{array}$ & $\begin{array}{c}\text { GBV-C/HGV-5'NCR- } \\
\text { positive } \\
\text { patients (\%) }\end{array}$ \\
\hline Blood donors & 71 & $22(31)^{*}$ & $7(10)$ & $7(10)^{* *}$ \\
Hepatitis A & 40 & $8(20)$ & $0(0)$ & $1(2.5)$ \\
Hepatitis B & 42 & $11(26)$ & $5(12)$ & $6(14)$ \\
Hepatitis non-A-C & 12 & $1(8)^{*}$ & $1(8)$ & $1(8)^{* *}$ \\
Total & 165 & $42(25)$ & $13(8)$ & $15(10)$ \\
\hline
\end{tabular}

${ }^{*} \mathrm{P}=0.165$ for comparison of TTV-DNA prevalence between blood donors and patients with non-A-C hepatitis (Fisher exact test);

${ }^{*} \mathrm{P}=1.000$ for comparison of GBV-C/HGV-5'NCR prevalence between blood donors and patients with non-A-C hepatitis (Fisher exact test)

Table 3. Comparison of acute hepatitis patients with and without serum TTV-DNA or GBV-C/HGV-RNA.

\begin{tabular}{|c|c|c|c|c|}
\hline \multirow[t]{2}{*}{ Clinical data } & \multicolumn{4}{|c|}{ Acute hepatitis $A, B$ and non- $A-C(N=94)$} \\
\hline & $\begin{array}{l}\text { TTV-DNA } \\
\text { positive }\end{array}$ & $\begin{array}{l}\text { TTV-DNA } \\
\text { negative }\end{array}$ & $\begin{array}{l}\text { GBV-C/HGV- } \\
5^{\prime} \mathrm{NCR} \text { positive }\end{array}$ & $\begin{array}{l}\text { GBV-C/HGV- } \\
\text { 5'NCR negative }\end{array}$ \\
\hline Number of patients & 20 & 74 & 8 & 86 \\
\hline Sex (male:female) & $14: 6$ & $45: 29$ & $3: 5$ & $56: 30$ \\
\hline $\begin{array}{l}\text { Age (years, } \\
\text { mean } \pm S D \text { ) }\end{array}$ & $23.40 \pm 12.50$ & $24.80 \pm 16.37$ & $32.25 \pm 18.01$ & $23.78 \pm 15.25$ \\
\hline Max ALT (x ULN) & $22.95 \pm 17.93$ & $24.46 \pm 18.52$ & $21.88 \pm 14.26$ & $24.35 \pm 18.70$ \\
\hline Max AST (x ULN) & $15.95 \pm 13.76$ & $18.59 \pm 19.11$ & $18.38 \pm 14.54$ & $18.00 \pm 18.43$ \\
\hline
\end{tabular}

See legend to Table 1 for explanation of abbreviations. There were no statistical differences. 
in 11 of 15 subjects who were 5'NCR-GBV$\mathrm{C} / \mathrm{HGV}$ positive. Six of these subjects had acute hepatitis B and 5 were blood donors. The GenBank accession numbers for these sequences are AY133292-AY133302. We identified six GBV-C/HGV isolates of genotype 1 and five of genotype 2 (three were subtype $2 \mathrm{a}$ and two subtype $2 \mathrm{~b}$ ). A phylogenetic tree was constructed and confirmed this genotype distribution (Figure 3).

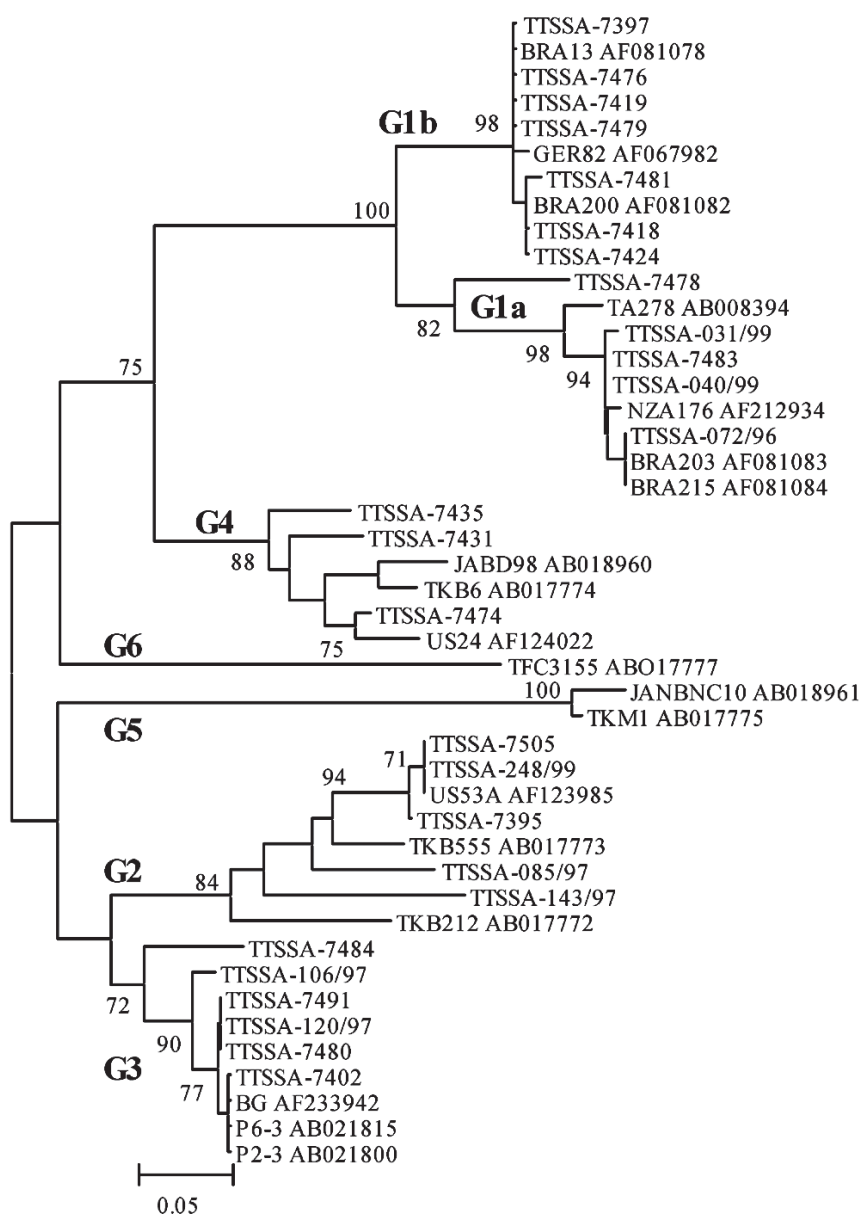

Figure 2. Neighbor-joining tree of 183 nt fragments of TTV. This corresponds to nt 1960-2142 of strain TA278 from previously published reference strains and from our study population. For previously published reference strains, the GenBank accession numbers are indicated. The genotype designations used correspond to designations from previous publications. They are indicated on the branches. The bootstrap test of phylogeny was performed with 1000 replicates and values equal to or higher than 70 are indicated.

\section{Discussion}

Confirmed acute cases of HEV infection have not been documented in Brazil. However, our results suggest that symptomatic hepatitis $E$ is the etiologic agent of some of the cases of acute sporadic hepatitis in the population that seeks primary medical care in the city of Salvador. We found that 2 of 12 patients with acute non-A-C hepatitis were anti-HEV IgG seropositive and one of them also had anti-HEV IgM detected in serum. To our knowledge, this is the first report of detection of anti-HEV IgM in serum of a patient with acute non-A-C hepatitis in Salvador, Northeastern Brazil. Interestingly, we also found seropositivity for anti-HEV IgM in 4 patients who had been diagnosed with acute hepatitis A, while none of the patients who had acute hepatitis B were anti-HEV IgM positive. Detection of HEV by PCR would be necessary to confirm the presence of the virus and to determine that co-infection of HAV and HEV indeed occurred. Nevertheless, our findings suggest that there was co-infection with HAV and HEV. Both viruses share a similar mode of transmission by the fecal-oral route (29). Thus, patients who are infected with HAV are probably at a higher risk to be co-infected with HEV. In fact, the prevalence of anti-HEV IgG antibody was significantly higher in the group of subjects with hepatitis A compared to the group with acute hepatitis B. This is in agreement with a previous study from Brazil that reported a higher rate of anti-HEV IgG antibody seropositivity in patients with acute hepatitis A compared to patients with acute hepatitis B and controls (14).

Among 26 serum samples subjected to TTV genotyping, 12 isolates were genotype 1. It should be noted that the primers we used do not permit the detection of all TTV genotypes, although they allow the detection of the main TTV genotypes reported in other studies. TTV genotypes 1 and 2 have been described in several countries including Ja- 
pan, Thailand, United Kingdom, and Germany. Other genotypes have also been reported in these regions $(19,36,37)$.

We found that TTV was highly prevalent among all groups studied, although the virus was less frequently detected in the non-A-C group. Moreover, ALT and AST levels were lower in patients infected with TTV compared to patients who were TTV negative, but these differences did not reach statistical significance. These findings suggest that TTV does not have an etiologic role in patients with acute hepatitis of unknown etiology and that it does not add to the severity of the necro-inflammatory activity of acute hepatitis caused by HAV or HBV.

The results of the studies that have analyzed the role of TTV in acute and chronic liver diseases have been controversial $(17,19$, 20,27,36). Nevertheless, it appears that TTV does not have a role in the etiology of acute and chronic liver disease. In a Japanese study, TTV was detected in $29 \%$ of patients with hepatitis A, $24 \%$ of patients with acute hepatitis B, $43 \%$ of patients with non-A-E hepatitis, and in $37 \%$ of the controls. There was no significant difference in aminotransferase levels between TTV-positive and TTV-negative patients (14). These findings appear to be similar to ours.

We were able to identify only GBV-C/ HGV isolates of genotypes 1 and 2. These appear to be the most prevalent GBV-C/ HGV genotypes found in Africa, and North America and Europe, respectively. GBV-C/ HGV genotype 3 isolates are found in Asia and among native American Indians from Colombia and Venezuela $(38,39)$. Perhaps this high prevalence of GBV-C/HGV genotypes 1 and 2 in our population may be explained by the fact that the population of Salvador mainly consists of African-Brazilians and of miscegenation of African-Brazilians and Whites (Mulattos), many of whom have a European and African ethnic background.

As previously demonstrated by other in- vestigators, the data reported here do not support a role for GBV-C/HGV in the etiology of acute non-A-C hepatitis. The high frequency of GBV-C/HGV in blood donors $(10 \%)$ is in agreement with rates found in blood donor populations in other Brazilian cities and elsewhere $(22,23,30)$.

Finally, it is interesting to note that the serum samples analyzed in this study were from patients who were referred by primary care public institutions through a sentinel program for hepatitis. Therefore, our results

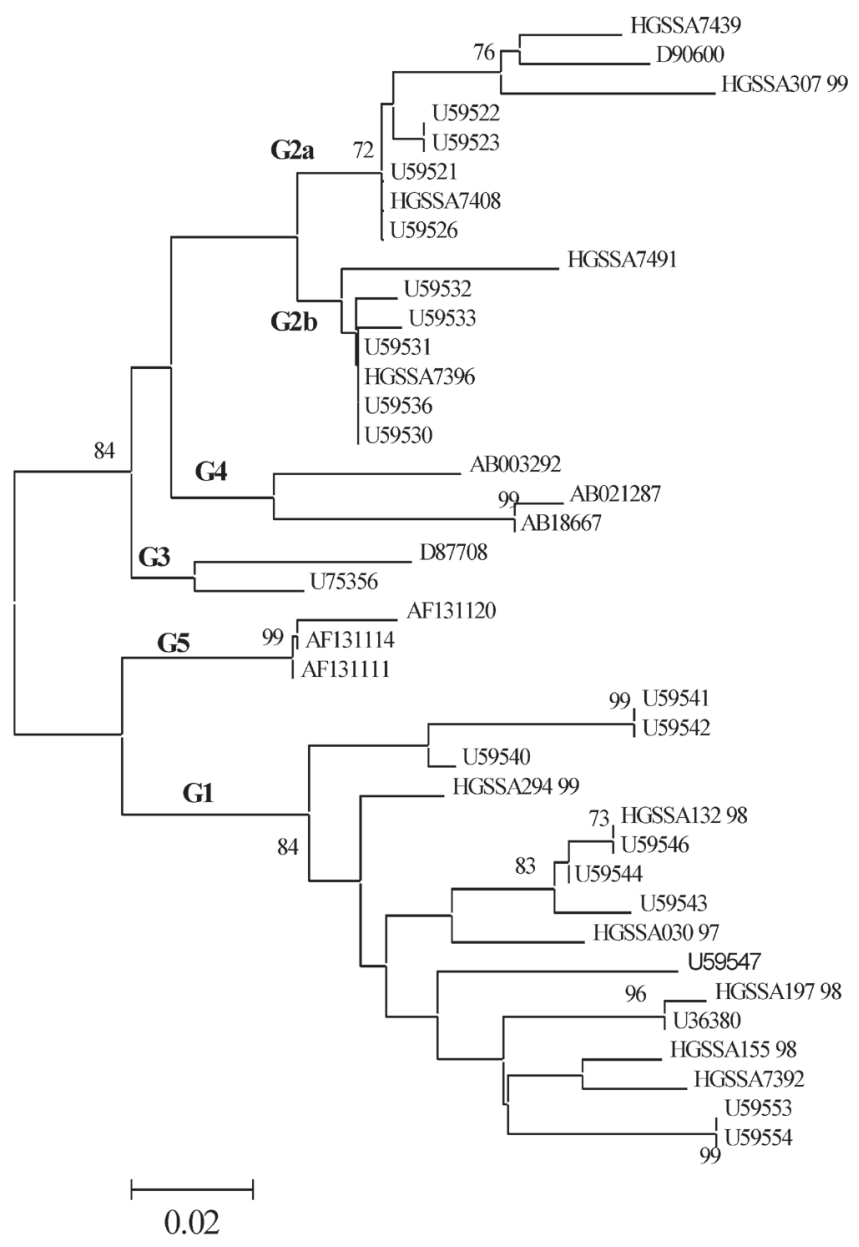

Figure 3. Neighbor-joining tree of $135 \mathrm{nt}$ fragments of GBV-C/HGV (5'NCR) from previously published reference strains and from our study population. For previously published reference strains, the GenBank accession numbers are indicated. The genotype designations used correspond to designations from previous publications. They are indicated on the branches. The bootstrap test of phylogeny was performed with 1000 replicates and values equal to or higher than 70 are indicated. 
correspond to findings observed in patients who seek primary care health institutions in the city of Salvador and are not necessarily referred to tertiary institutions. On the other hand, this is a retrospective study and patients were selected on the basis of the availability of stored serum samples. Therefore, further studies are necessary to confirm and extend our findings.

\section{Acknowledgments}

We wish to thank the following persons for their assistance and/or support for this study: Dr. Aurelino Reis (Hemocentro da Bahia, Salvador, BA, Brazil), Dr. Nelma Santana, Dr. Marcos C. Lyra, Dr. Maxuel Oliveira (Serviço de Gastro-Hepatologia, Universidade Federal da Bahia and Hospital São Rafael, Salvador, BA, Brazil) and Jussara Botto (Laboratório Central da Bahia (LACEN), Salvador, BA, Brazil).

\section{References}

1. Pannuti CS, de Mendonca JS, Pereira ML, Carvalho MJ \& Amato Neto V (1985). Sporadic acute viral hepatitis A, B and non-A non-B. A prospective study of 150 consecutive cases in São Paulo, Brazil. Tropical and Geographical Medicine, 37: 136-138.

2. Abuzwaida AR, Sidoni M, Yoshida CF \& Schatzmayr HG (1987). Seroepidemiology of hepatitis $A$ and $B$ in two urban communities of Rio de Janeiro, Brazil. Revista do Instituto de Medicina Tropical de São Paulo, 29: 219-223.

3. Vitral CL, Yoshida CF, Lemos ER, Teixeira CS \& Gaspar AM (1998). Age-specific prevalence of antibodies to hepatitis $A$ in children and adolescents from Rio de Janeiro, Brazil, 1978 and 1995. Relationship of prevalence to environmental factors. Memórias do Instituto Oswaldo Cruz, 93: 1-5.

4. dos Santos JI, Lopes MA, Deliege-Vasconcelos E, Couto-Fernandez JC, Patel BN, Barreto ML, Ferreira Junior OC \& Galvao-Castro B (1995). Seroprevalence of HIV, HTLV-I/II and other perinatally-transmitted pathogens in Salvador, Bahia. Revista do Instituto de Medicina Tropical de São Paulo, 37: 343-348.

5. Clemens SA, da Fonseca JC, Azevedo T, Cavalcanti A, Silveira TR, Castilho MC \& Clemens R (2000). Hepatitis A and hepatitis B seroprevalence in 4 centers in Brazil. Revista da Sociedade Brasileira de Medicina Tropical, 33: 1-10.

6. Ferraz ML, Yoradjian A, Barbieri A, Figueiredo V, Lopes Neto E, Cruz CN \& Silva AE (1998). Epidemiology of acute hepatitis B in a university hospital in São Paulo, Brazil: retrospective study of two fiveyear periods. São Paulo Medical Journal, 116: 1695-1699.

7. Lewis-Ximenez LL, do O KM, Ginuino CF, Silva JC, Schatzmayr HG, Stuver S \& Yoshida CF (2002). Risk factors for hepatitis B virus infection in Rio de Janeiro, Brazil. BMC Public Health, 2: 26.

8. Parana R, Vitvitski L, Andrade Z, Trepo C, Cotrim H, Bertillon P, Silva F, Silva L, de Oliveira IR \& Lyra L (1999). Acute sporadic non-A, non$B$ hepatitis in Northeastern Brazil: etiology and natural history. Hepatology, 30: 289-293.

9. Reyes GR, Purdy MA, Kim JP, Luk KC, Young LM, Fry KE \& Bradley DW (1990). Isolation of a cDNA from the virus responsible for enterically transmitted non-A, non-B hepatitis. Science, 247: 13351339.

10. Bradley DW, Purdy MA \& Reyes GR (1991). Hepatitis E virus genome. Molecular features, expression of immunoreactive proteins and sequence divergence. Journal of Hepatology, 4 (Suppl): S152-
S154.

11. Hyams KC, Purdy MA, Kaur M, McCarthy MC, Hussain MA, elTigani A, Krawczynski K, Bradley DW \& Carl M (1992). Acute sporadic hepatitis $\mathrm{E}$ in Sudanese children: analysis based on a new Western blot assay. Journal of Infectious Diseases, 165: 10011005.

12. Bryan JP, Tsarev SA, Iqbal M, Ticehurst J, Emerson S, Ahmed A, Duncan J, Rafiqui AR, Malik IA \& Purcell RH (1994). Epidemic hepatitis $\mathrm{E}$ in Pakistan: patterns of serologic response and evidence that antibody to hepatitis $E$ virus protects against disease. Journal of Infectious Diseases, 170: 517-521.

13. Paul DA, Knigge MF, Ritter A, Gutierrez R, Pilot-Matias T, Chau KH \& Dawson GJ (1994). Determination of hepatitis E virus seroprevalence by using recombinant fusion proteins and synthetic peptides. Journal of Infectious Diseases, 169: 801-806.

14. Parana R, Cotrim HP, Cortey-Boennec ML, Trepo C \& Lyra L (1997). Prevalence of hepatitis $E$ virus IgG antibodies in patients from a referral unit of liver diseases in Salvador, Bahia, Brazil. American Journal of Tropical Medicine and Hygiene, 57: 60-61.

15. Souto FJ, Fontes CJ, Parana R \& Lyra LG (1997). Short report: further evidence for hepatitis $\mathrm{E}$ in the Brazilian Amazon. American Journal of Tropical Medicine and Hygiene, 57: 149-150.

16. Goncales NS, Pinho JR, Moreira RC, Saraceni CP, Spina AM, Stucchi $R B$, Filho AD, Magna LA \& Goncales Junior FL (2000). Hepatitis $E$ virus immunoglobulin $\mathrm{G}$ antibodies in different populations in Campinas, Brazil. Clinical and Diagnostic Laboratory Immunology, 7: 813-816.

17. Nishizawa $T$, Okamoto $H$, Konishi $K$, Yoshizawa $H$, Miyakawa $Y$ \& Mayumi M (1997). A novel DNA virus (TTV) associated with elevated transaminase levels in post-transfusion hepatitis of unknown etiology. Biochemical and Biophysical Research Communications, 241: 92-97.

18. Mushahwar IK, Erker JC, Muerhoff AS, Leary TP, Simons JN, Birkenmeyer LG, Chalmers ML, Pilot-Matias TJ \& Dexai SM (1999). Molecular and biophysical characterization of TT virus: Evidence for a new virus family infecting humans. Proceedings of the National Academy of Sciences, USA, 96: 3177-3182.

19. Naoumov NV, Petrova EP, Thomas MG \& Williams R (1998). Presence of a newly described human DNA virus (TTV) in patients with liver disease. Lancet, 352: 195-197. 
20. Ikeda $H$, Takasu M, Inoue $K$, Okamoto $H$, Miyakawa $Y$ \& Mayumi M (1999). Infection with an unenveloped DNA virus (TTV) in patients with acute or chronic liver disease of unknown etiology and in those positive for hepatitis C virus RNA. Journal of Hepatology, 30: 205212.

21. Tanaka $H$, Okamoto $H$, Luengrojanakul $P$, Chainuvati $T$, Tsuda $F$, Tanaka T, Miyakawa Y \& Mayumi M (1998). Infection with an unenveloped DNA virus (TTV) associated with posttransfusion nonA to $G$ hepatitis in hepatitis patients and healthy blood donors in Thailand. Journal of Medical Virology, 56: 234-238.

22. Simons JN, Leary TP, Dawson GJ, Pilot-Matias TJ, Muerhoff AS, Schlauder GG, Desai SM \& Mushahwar IK (1995). Isolation of novel virus-like sequences associated with human hepatitis. Nature Medicine, 1: 564-569.

23. Halasz R, Weiland O \& Sallberg M (2001). GB virus C/hepatitis G virus. Scandinavian Journal of Infectious Diseases, 33: 572-580.

24. Williams CF, Klinzman D, Yamashita TE et al. (2004). Persistent GB virus $\mathrm{C}$ infection and survival in HIV-infected men. New England Journal of Medicine, 350: 981-990.

25. Tillmann $H L$, Heiken $H$ \& Knapik-Botor $A$ (2001). Infection with GB virus $\mathrm{C}$ and reduced mortality among HIV-infected patients. New England Journal of Medicine, 345: 715-724.

26. Silva LK, Parana R, Souza SP, Berby F, Kay A, Trepo C, Santana N, Cotrim H, Lyra LG \& Reis MG (2000). Hepatitis C virus genotypes in a northeastern area of Brazil. American Journal of Tropical Medicine and Hygiene, 62: 257-260.

27. Okamoto $H$, Nishizawa $T$, Kato $N$, Ukita $M$, Ikeda $H$, lizuka $H$, Miyakawa Y \& Mayumi M (1998). Molecular cloning and characterization of a novel DNA virus (TTV) associated with posttransfusion hepatitis of unknown etiology. Hepatology Research, 10: 1-16.

28. Chomczynski P \& Sacchi N (1987). Single-step method of RNA isolation by acid guanidinium thiocyanate-phenol-chloroform extraction. Analytical Biochemistry, 162: 156-159.

29. Kwok S \& Higuchi R (1989). Avoiding false positives with PCR. Nature, 339: 237-238.

30. Pinho JR, Zanotto PM, Ferreira JL et al. (1999). High prevalence of
GB virus $\mathrm{C}$ in Brazil and molecular evidence for intrafamilial transmission. Journal of Clinical Microbiology, 37: 1634-1637.

31. Leary TP, Muerhoff AS, Simons JN, Pilot-Matias TJ, Erker JC, Chalmers ML, Schlauder GG, Dawson GJ, Desai SM \& Mushahwar IK (1996). Consensus oligonucleotide primer for the detection of GB virus $\mathrm{C}$ in human cryptogenic hepatitis. Journal of Virological Methods, 56: 119-121.

32. Erker JC, Desai SM \& Mushahwar IK (1998). Rapid detection of GB virus C RNA by reverse transcription-polymerase chain reaction (RT$\mathrm{PCR}$ ) using primers derived from the 5 'nontranslated region. Journal of Virological Methods, 70: 1-5.

33. Thompson JD, Gibson TJ, Plewniak F, Jeanmougin F \& Higgins DG (1997). The CLUSTAL_X windows interface: flexible strategies for multiple sequence alignment aided by quality analysis tools. Nucleic Acids Research, 25: 4876-4882.

34. Kumar S, Tamura K, Jakobsen IB \& Nei M (2001). MEGA2: molecular evolutionary genetics analysis software. Bioinformatics, 17: 1244-1245.

35. Kimura M (1980). A simple method for estimating evolutionary rates of base substitutions through comparative studies of nucleotide sequences. Journal of Molecular Evolution, 16: 111-120.

36. Gimenez-Barcons M, Forns X, Ampurdanes S et al. (1999). Infection with a novel human DNA virus (TTV) has no pathogenic significance in patients with liver diseases. Journal of Hepatology, 30: 10281034.

37. Kanda $T$, Yokosuka O, Ikeuchi $T$, Seta $T$, Kawai S, Imazeki F \& Saisho $H$ (1999). The role of TT virus infection in acute viral hepatitis. Hepatology, 29: 1905-1908.

38. Tanaka Y, Mizokami M, Orito E et al. (1998). GB virus C/hepatitis G virus infection among Colombian native Indians. American Journal of Tropical Medicine and Hygiene, 59: 462-467.

39. Loureiro CL, Alonso R, Pacheco BA, Uzcategui MG, Villegas L, Leon G, De Saez A, Liprandi F, Lopez JL \& Pujol FH (2002). High prevalence of $\mathrm{GB}$ virus $\mathrm{C} /$ hepatitis $\mathrm{G}$ virus genotype 3 among autochthonous Venezuelan populations. Journal of Medical Virology, 68: $357-$ 362 